Article

\title{
E.U. and China trends in trade in challenging times
}

\author{
Irena Jindřichovská ${ }^{1}$, Erginbay Uğurlu' ${ }^{2}$ * \\ 1 Metropolitan University Prague, Czech Republic; irena.jindrichovska@mup.cz \\ 2 İstanbul Aydın University, Turkey, erginbayugurlu@aydin.edu.tr \\ * Correspondence: erginbayugurlu@aydin.edu.tr
}

\begin{abstract}
The sudden and abrupt rise of COVID-19 became a challenge for the world economy. In this paper, we investigate the changes in a trend of mutual trade between the EU-15 countries and China during the demanding times of the COVID-19 crisis. We use monthly data for Chinese export to the E.U. (2018:01 - 2020:05) and import from the E.U. (2018:01 - 2020:07) relying on the data from the open-source TradeMap developed by the International Trade Centre UNCTAD/WTO (ITC). Overall, there is the obvious decline of 13-32 per cent in worldwide trade as predicted by the WTO. This affected China as the main trading partner of electronic devices and medical supplies. The trade between the E.U. and China has decreased, but the major change in demand brought an alteration in commodities structures and the re-orientation of Chinese export production. In the first five months of 2020, we have witnessed the strong engagement of the Chinese economy in the production of goods newly in high demand - mainly articles strongly related to healthcare and medical equipment. Thus, we have observed that the Chinese were very flexible in changing the structure of their exports triggered by the COVID-19 crisis. This flexibility is worth further exploration especially because the COVID-19 crisis is still not over and new data and changing results can be expected.
\end{abstract}

Keywords: Export, import, international trade, the flexibility of production, China, E.U.

\section{Introduction}

The aim of this paper is to investigate the trade relations between the two largest world economic centers, the E.U. and China, and how it was affected by the COVID-19 crisis. Our motivation is to explore the changes in mutual economic relations resulting from the pandemic and to assess how the Chinese economy has reacted to this challenge. In our exploration, we use the EU 15 countries to represent Europe. We use monthly data on the bilateral trade between China and the EU 15 for the period 2018-2020. We found that China has reacted very flexibly to the challenges brought by COVID-19 and, up to now (December 2020), we have witnessed that the economy has been slowed down. Nevertheless, it seems that the Chinese have succeeded in avoiding the second wave of the pandemic, which is affecting the other world economic centers - the EU and the USA.

Our paper offers three contributions to the literature. First, it is a paper which investigates international trade between trade centers, namely Europe and China. Secondly, our analysis shows that the re-orientation of Chinese production patterns is due to COVID-19. Thirdly, the data we use for our analysis is the monthly bilateral trade data between EU and China.

In our analysis, we have verified that China has flexibly adjusted to the increased demand for protective medical equipment due to COVID-19 to satisfy the dramatically increased demand from various parts of the world, including Europe.

An economic slowdown has been apparent in all the major economic centers of the world, the EU, the USA, and China, since 2018. This has inevitably impacted the scope of trade among these three centers Xu (2019); Chen, Zhao, Lai, Wang, and Xia (2019); Xu (2019); Civín and Smutka (2020); Oravský, Tóth, and Bánociová (2020) and Thorbecke (2020). 
Before, world exports had been steadily increasing since the major financial crisis, in 2009, when it reached a minimum level of 19,255 trillion USD. Subsequently, there was a slowdown, in 2016, following several events starting with the January fall in the Chinese stock market, which was echoed in stock markets around the world due to the increased importance of the Chinese economy. Furthermore, there was the British government decision to leave the EU after 23 years in June 2016. These had a significant impact on the OPEC countries as shown by their decision to cut crude oil production, which impacted the oil-producing countries.

Moreover, there was the end of sanctions against Iran. Several measures were put in place by President Trump affecting the U.S. market - modifications of the NAFTA agreement, which was perceived by President Trump as unfavourable to the USA, complaints against the devaluation of Chinese Yuan and promises to tax more heavily American firms which place production overseas and freeing funds to support the American economy. For more details, see The Economic Times News.

Although world trade was growing in 2018, the growth of world merchandise trade was lower than predicted by World Trade Statistical Review 2019 (WTO, 2019). In 2019, the declining trend continued because of trade tensions. Growth has slowed because of weaker output growth in the major economies and "The loss of momentum in trade and GDP [which] is partly due to tighter monetary policy, increased financial volatility and the raising of tariffs on widely traded goods in major economies. Trade tensions appear to have contributed significantly to the slowdown". ${ }^{1}$ Nevertheless, the major, and more abrupt, decline came early in 2020 with the arrival of the pandemic, which is having an impact on virtually all production sectors and slowing commerce in all the major centers of world trade.

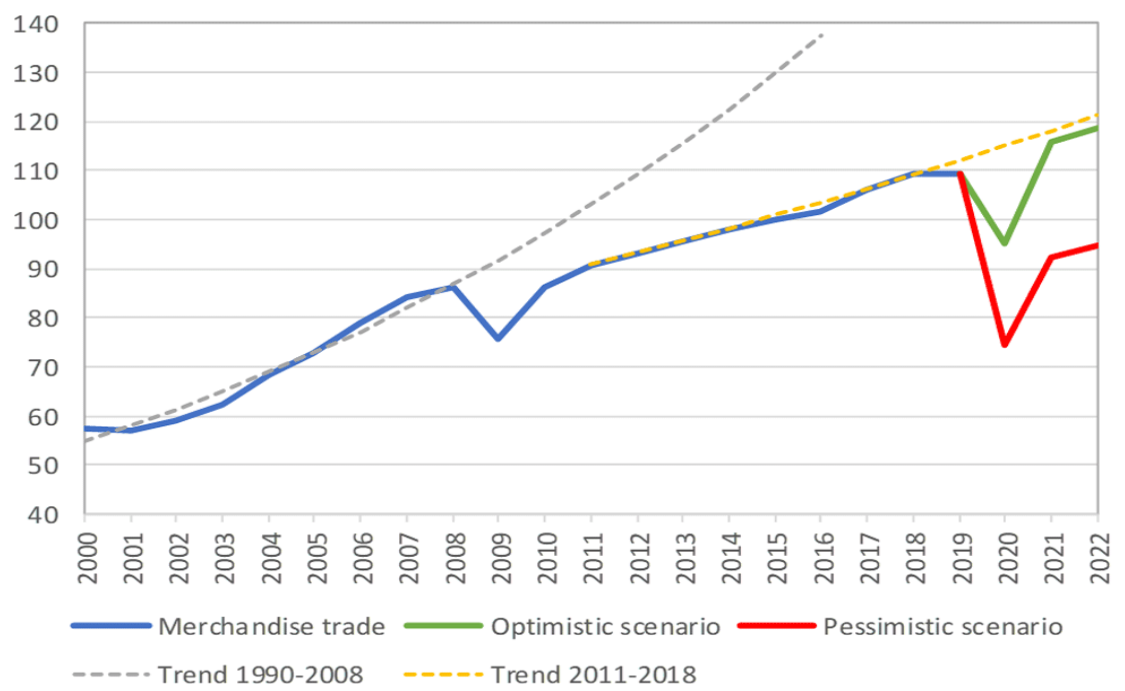

Figure 1. World merchandise trade volume, 2000-2022 Index, 2015=100, Source: WTO Secretariat.https://www.wto.org/english/news_e/pres20_e/pr855_e.htm

The graph depicts world merchandise trade volumes, starting in 2000, including optimistic and pessimistic predictions. (It already included predictions of the COVID-19 crisis.) This graph was created by the World Trade Organization, early in 2020; see details in the footnote.

In late December 2019, a previous unidentified coronavirus was identified in the Huanan Seafood Wholesale Market, in Wuhan, Hubei, China. This virus is the cause of a disease which is officially named Coronavirus Disease-2019 (COVID-19) that has spread across the world (Wu, Chen, and Chan, 2020; McAleer, 2020). COVID-19 has had a major negative social and economic effect on the regions of the world regardless of income level, and it continues to do so. According to UNIDO (2020), the

\footnotetext{
1 855PRESS RELEASE 8 April 2020 "Trade set to plunge as COVID-19 pandemic upends global economy "available at
} https://www.wto.org/english/res e/statis e/wts2019 e/wts2019chapter03 e.pdf page 17, accessed on September 27, 2020. 
impacts are felt on industrial production, trade, international trade, manufacturing, education, etc. (Zhang, Wang, Yang, Wang, 2020; and Wang, Cheng, Yue, McAleer (2020). For this reason, countries all over the world have implemented both economic and social measures.

On March 17, 2020, the European Council and the European Commission announced some measures in response to the COVID-19 outbreak. On March 14, 2020, the export of "personal protective equipment" had been restricted for destinations outside of the EU. The EU Member States endorsed "Guidelines for border management measures." Other restrictions came from the World Trade Organization; "WTO Appellate Body jurisprudence, it appears that the current measures may be justified on the grounds of Article XI:2 of the GATT as temporary measures because of critical shortages of essential goods" (Carreño, Dolle, Medina, and Brandenburger, 2020).

Earlier academic literature on world economic trade observed, even before 2020, that an economic slowdown was apparent in all the major economic centers of the world. Xu (2019) characterizes the four major factors that impeded China's economic growth: the fall in consumption demand, investment demand, and export demand. Del Rio Lopez and Gordo Mora (2019) claim in the World Economic Outlook that they see behind the slowdown, among other factors, the possible proliferation of protectionist measures, severe financial market adjustments. Similar analyses were also performed in the USA. For example, authors Akcigit and Ates (2019) claim that heavy use of intellectual property protection by market leaders to limit the diffusion of knowledge has contributed to the economic slowdown.

This paper is structured as follows: Part one provides the introduction and motivation. Part two concentrates on the background and macroeconomic conditions of China. Part three explains the used data and provides an analysis of international trade between the EU and China. Part four comments on our findings and provides the conclusions of the study. It furthermore explains the limitations of the study and suggests areas for future research.

\section{Background and Macroeconomic Conditions of China}

China has become the largest nation in the international trade of goods since 2009 (Jin, $\mathrm{Li}$, and $\mathrm{Wu}, 2016)$. China is the most important country in the world economy. China is also the second largest source and destination of FDI (Jin, $\mathrm{Li}$, and $\mathrm{Wu}, 2016$ ).

The top three world trading countries are: China, the USA and Germany. The EU was the largest exporter of manufactured goods in 2017 (Yüksel, Dinçer, and Meral, 2019). However, now China is the largest exporter in the world based on 2020 data (Bekkers, Koopman and Rêgo, 2020). Lin (2011) determined the performance of China as "extraordinary" and "unprecedented."

In 2015, China started a program entitled "Made in China 2025", which includes a ten-year plan to strengthen the Chinese position in the manufacturing of high-value-added products (Bencivelli and Tonelli, 2020). This program strives to integrate new technologies that are the outcome of the fourth industrial revolution into the Chinese economy. Moreover, in line with this plan, China has supported domestic producers. Besides its existing high share in the world economy, after this program and new supports are provided, it was expected that China would become an even more important actor in the world economy. China is nowadays a major trade partner for many countries.

The European Union (EU) is one of the important trade partners of China. The inflow of foreign direct investment is, however, much smaller compared to other regions, such as the USA, with $0.3 \%$ of total GDP in 1995 to 2\% of total GDP in 2015, and 3\% of total GDP (is \$538 billion) in 2016. Direct investment by China in Europe rose by 72.7\% (\$18.46) in 2017 (Bencivelli and Tonelli, 2020). Furthermore, in 2013, the Chinese government launched its Belt and Road Initiative (BRI) and, thus, the trading volume between China and European countries increased by $15.2 \%$ in 2017 (Bekkers, Koopman and Rêgo, 2020).

In our study, we chose the EU-15 countries to represent Europe. The reason is that EU15 is still a good statistical representation of the entire EU because it represents $91.4 \%$ of the EU28's GDP (Halicioglu and Ketenci, 2018).

China is one of the three chief economic centers of the world, together with the EU and the USA. Most world trade traffic takes place between these three destinations. China belongs to a group of 
five fast-growing economies (the BRICS) and it has been growing fast for several decades. China is now the world's second-largest economy. (See Table 1 for macroeconomic results from the last nine years.)

China has experienced uninterrupted trade surpluses since 1993. It has become the world's biggest trading nation since 2013. China is now the second-biggest economy, and it is doing quite well since the financial crisis in 2008; its public debt has reached 17\% of the country's GDP. China's external position is very stable, and it has a positive trading balance. Its current account has recorded a surplus in every year since 1994.

In 2020, a slowdown was expected. This slowdown is a result of several influences, including the COVID-19 pandemic and continuing economic sanctions from the USA. However, according to the latest results, it seems that the downturn will not be as bad as previously expected because of a relatively fast recovery from the pandemic. ${ }^{2}$

Table 1. Macroeconomic Characteristics of Recent Development (China)

\begin{tabular}{|c|c|c|c|c|c|c|c|c|c|}
\hline Variable & 2011 & 2012 & 2013 & 2014 & 2015 & 2016 & 2017 & 2018 & 2019 \\
\hline $\begin{array}{l}\text { Economic growth of } \\
\text { GDP intra year }\end{array}$ & 9.5 & 7.9 & 7.8 & 7.3 & 6.9 & 6.8 & 6.9 & 6.7 & 6.1 \\
\hline GDP (USD billion) & 7.592 & 8.575 & 9.694 & 10.480 & 10.925 & 11,247 & 12,313 & 13,837 & 14,298 \\
\hline $\begin{array}{l}\text { Population in } \\
\text { millions }\end{array}$ & 1.347 & 1.354 & 1.361 & 1.368 & 1.375 & 1,383 & 1,390 & 1,395 & 1,400 \\
\hline GDP per capita & 5.635 & 6.333 & 7.124 & 7.662 & 7.948 & 8,134 & 8,858 & 9,916 & 10,212 \\
\hline Export (USD bill) & 1.898 & 2.049 & 2.209 & 2.342 & 2.272 & 2,098 & 2,263 & 2,487 & 2,499 \\
\hline Import (USD bill) & 1.744 & 1.819 & 1.952 & 1.959 & 1.681 & 1,588 & 1,844 & 2,136 & 2,078 \\
\hline $\begin{array}{c}\text { Balance } \\
\text { (export/import) }\end{array}$ & 1.088 & 1.126 & 1.132 & 1.196 & 1.352 & 1.321 & 1.227 & 1.164 & 1.206 \\
\hline Inflation rate $(\mathrm{CPI})$ & 5.4 & 2.6 & 2.6 & 2.0 & 1.4 & 2.0 & 1.6 & 2.1 & 2.9 \\
\hline $\begin{array}{c}\text { Consumption } \\
\text { (Annual variation) }\end{array}$ & 11.0 & 9.1 & 7.3 & 7.7 & 7.5 & 8.6 & 6.8 & 9.5 & 6.8 \\
\hline $\begin{array}{l}\text { Public debt ( } \% \text { of } \\
\text { GDP) }\end{array}$ & 14.7 & 14.4 & 14.6 & 14.9 & 15.5 & 16.1 & 16.2 & 16.3 & 17.0 \\
\hline
\end{tabular}

Source: China statistical yearbook and own elaboration https://www.focus-economics.com/countries/china

Recovery is apparent in all sectors, and it started with the reopening of the global economy and robust demand for health products. The economic outlook is better than expected. China has prepared well for the second wave of COVID-19 and has increased the production of necessary health products. Since the second quarter, China has been able to deliver medical equipment to other parts of the world, including Europe. ${ }^{3}$

${ }^{2}$ China Economic Outlook available at https://www.focus-economics.com/countries/china

${ }^{3}$ Ensuring the availability of supplies and equipment: https://ec.europa.eu/info/live-work-travel-eu/ coronavirus-response/public-health_en\#ensuring-the-availability-of-supplies-and-equipment accessed on December $12,2020$. 
In 2020, the expected GDP growth is $3.20 \%$ and $5.6 \%$ for 2021 according to the economic forecasts China - Economic Forecasts - 2020-2022 Outlook, which is a drop compared with $6.1 \%$ in 2019. According to IBIS World (2020), the fastest-growing industries in 2020 in China are Solar Power Generation 32.2\%; Internet Services 30.7\%; Online Games 27.2\%; Online Shopping 22.0\%; Optical Fibre and Cable Manufacturing 20.3\%.

According to recent data and reports in 2020, one of the most prominent export industries was medical goods and drugs. Also, the private segment helped to increase growth. As to trade, exports decreased in January, but the slump in exports then became a rise to an even higher level shortly after due to specific export items like "textile face masks, surgical masks disposable face masks and single-use drapes". Therefore, even though the decline was expected and visible since the beginning of 2020, the trend seems to be returning to a growth trajectory. However, we can witness a specific shift from Chinese traditional export articles. These were, until the time of COVID-19, mainly telecommunications and I.T. devices and their spare parts, semiconductors and, of course, toys and baby carriages. This rapid development, in early 2020, shows that Chinese producers are able to convert their production facilities very quickly to meet new demand in new market segments.

Gruszczynski (2020) states that at first, COVID-19 was seen as a problem of the South-East Asian countries but, later on, it was understood that it is a worldwide problem. According to Baldwin and di Mauro (2020), COVID-19 caused both a supply and demand shock and has an impact on the international trade in goods and services. The data shows that about $55 \%$ of world supply and demand (GDP), about $60 \%$ of world manufacturing and $50 \%$ of world manufacturing exports decreased. We aim to see if COVID-19 has had an effect on the imports of the European Union from China. COVID-19 is expected to have an impact on the European Union's economy and international trade because of the lockdown of the economy or "social lockdown".

The first social lockdown for COVID-19 was initiated in China in the last week of January 2020 in Wuhan city, and it was continued in Beijing in China (McAleer, 2020). The second country which adopted social lockdown was Italy on February 21, 2020 (Paital, Das, and Parida, 2020). The chronology of lockdown could be evidence of the trading relationship between China and Europe. Because of the high number of COVID-19 cases in Italy, in other words in Europe, the second lockdown was in Europe.

\section{Data and Analysis}

To investigate the bilateral trade between the two major economic centers, we analyze and discuss both directions of trade flows: imports to Europe from China for January 2018 to May 2020 and imports to China from Europe for January 2018 to July 2020. The data were collected from TradeMap.org. For the analysis of Europe, import from China we use the import data of EU15 countries and analyze the effect on the European zone. On the TradeMap website, data is presented in the Harmonized System (H.S.), which is the classification based on the World Customs Organization. The H.S. uses different levels of digits for the products to classify traded goods on a common basis for customs purposes. In this research, we use 99 chapters (groups of products; hereafter, we use "a product" instead of "a chapter"), which are consolidated from the 5300 products. The H.S. for classifying goods is a six-digit code system which consists of headings and subheadings, arranged in 99 chapters, and grouped in 21 sections. The six digits can be broken down into three parts. The first two digits we use to identify the chapter of the goods, the next two digits to identify groupings within that chapter, and the last two digits to identify more specific groupings (TradeMap, 2020).

The source data represent the values of 99 products from 2018:01 to 2020:05 for imports and 2020:07 for exports. We use the monthly data to see the effect more clearly. To present our analysis in a broader context, we have started our exploration from January 2018 to see the movement of the bilateral trade before the COVID-19 outbreak. The data set finishes with the last published data at the time of performing this analysis 
Since we explore the movements of data in a period shorter than one year, we need to analyze more frequent data. Thus, we have used monthly data, which was the shortest period that could be found.

\subsection{Import to Europe from China}

For the analysis of Chinese Exports to Europe, we use the import data of EU15 countries and analyze the effect on the European zone. In the TradeMap website data is presented in the Harmonized System (H.S.), which is the classification based on the World Customs Organization. The H.S. uses a six-digit system for classifying goods (TradeMap, 2020).

In this section, we use 99 chapters (groups of products; hereafter we use "a product" instead of "a chapter") of imports from China to the European Union (EU 15) from 2018:01 to 2020:05. We use monthly data to see the effect more clearly. To present our analysis in a broader context, we have started our exploration from January 2018 to see the movement of bilateral trade before the COVID-19 outbreak. The data set finishes with the last published data, which is May 2020 for exports from China and July 2020 for imports into China.

The difference between the values of import of the EU15 of each product is very divergent; the values are not homogenous. The amount of some products was ten times greater than others. To organize our analysis, we had to choose the main products. To find the main trade products of bilateral trade, we calculated the proportion of each product in the total trade. Figure 2 shows the share of each product in total trade.
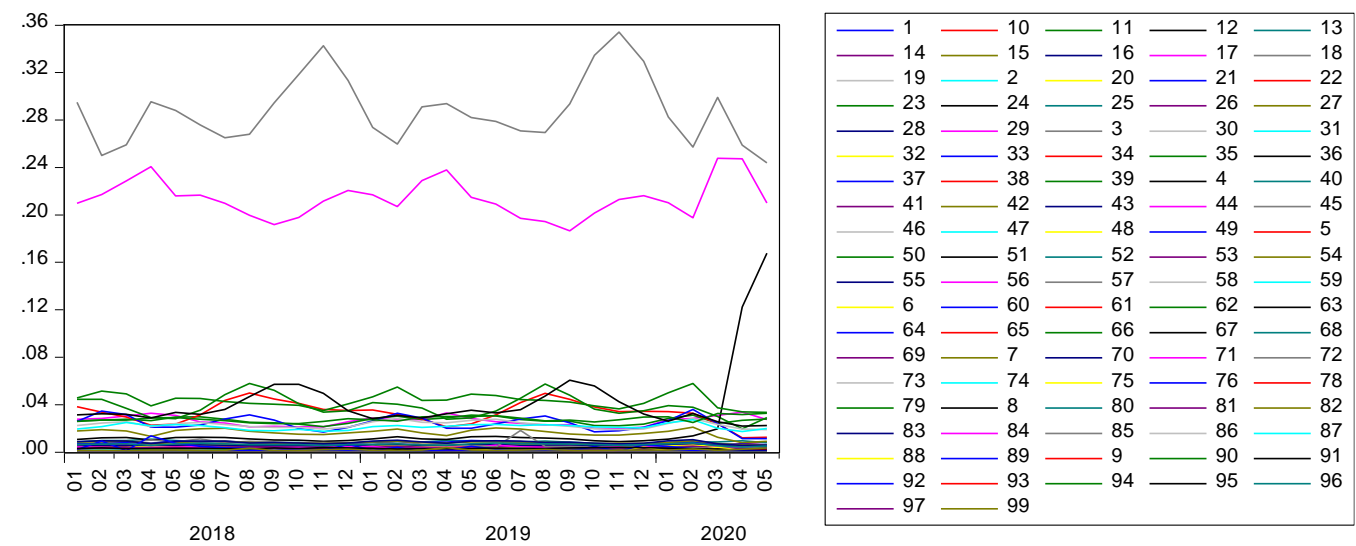

Figure 2. EU Import Shares of Products by year. Source: own investigation

In many cases, the share of the given product of total exports was less than $1 \%$. Therefore, we have omitted some products for greater clarity. We have selected the products which had a greater share than $5 \%$ of total trade in any month except apparel knitted products. The highest value of apparel knitted is $4.9 \%$, but we have included this article because it is very close to $5 \%$. Seven products fulfilled this criterion. In 99 products/products, we have chosen the products with H.S. codes $61,62,63,84,85,94$, and 95 . Hereafter, we will use short names for the products. These are apparel knitted for 61, apparel not knitted for 62, other made-up textiles for 63, machinery for 84 , electrical machinery for 85 , furniture for 94 , and toys for 95 . Figure 2 shows that machinery and electrical machinery are the main import products of EU15 countries from China. Two of them always have a higher proportion than $20 \%$ of total trade and, furthermore, electrical machinery reaches and exceeds $30 \%$ of the total trade.

To demonstrate our method of selection, we first present Figure 2 to show all products. Here, it can be seen that it is hard to recognize the values of the main products, which we have identified above. Therefore, we separated these main products in Figure 3. 


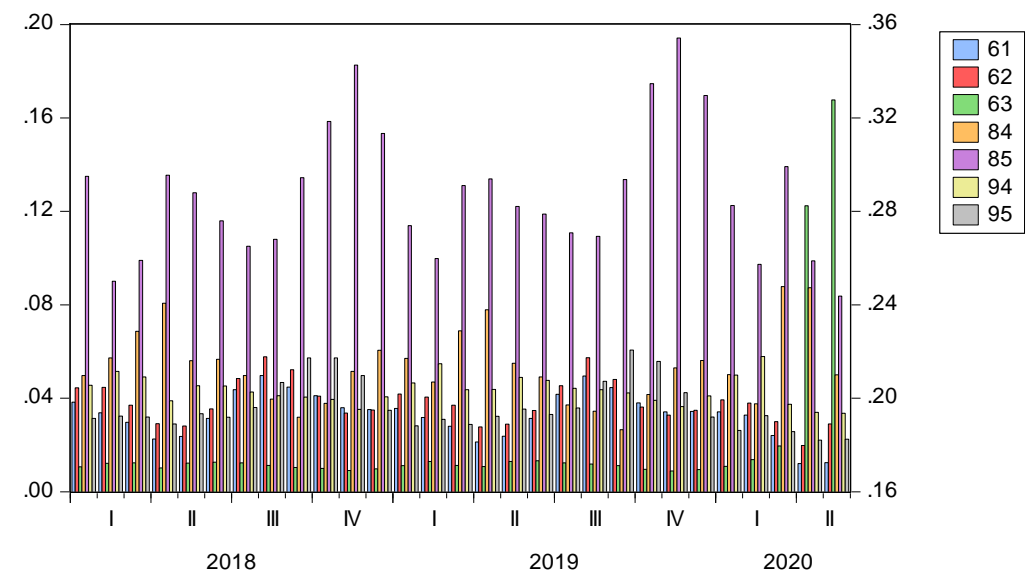

Figure 3. EU Import Shares of the Selected Articles by year. Source: own investigation

Figure 3 shows the increase or decrease in the share of the products by month. Except for apparel knitted, all articles have at least one 5\% share. In the figure, we can identify machinery and electrical machinery from the right axis and the rest of them from the left axis. However, we present Figure 3 here to show why we have chosen these products. For detailed research, we use the values of the products instead of their shares.

If the seasonality effect were identified, we could adjust for the seasonality, but in our situation, we do not know what volume of data are affected by seasonality and what volume of data comes from the effect of COVID-19. That is why we used three sub-samples to identify seasonality using a graph. Our procedure is described here:

As the next step, we attempted to separate the effect of seasonality from the effect of COVID-19. The first subsample represents 2018 to see the usual pattern of imports of articles from China to the EU The second sample covers 2019 to see the variation from month to month in one year, and the last subsample captures 2020 to see the effect of the COVID-19 outbreak.

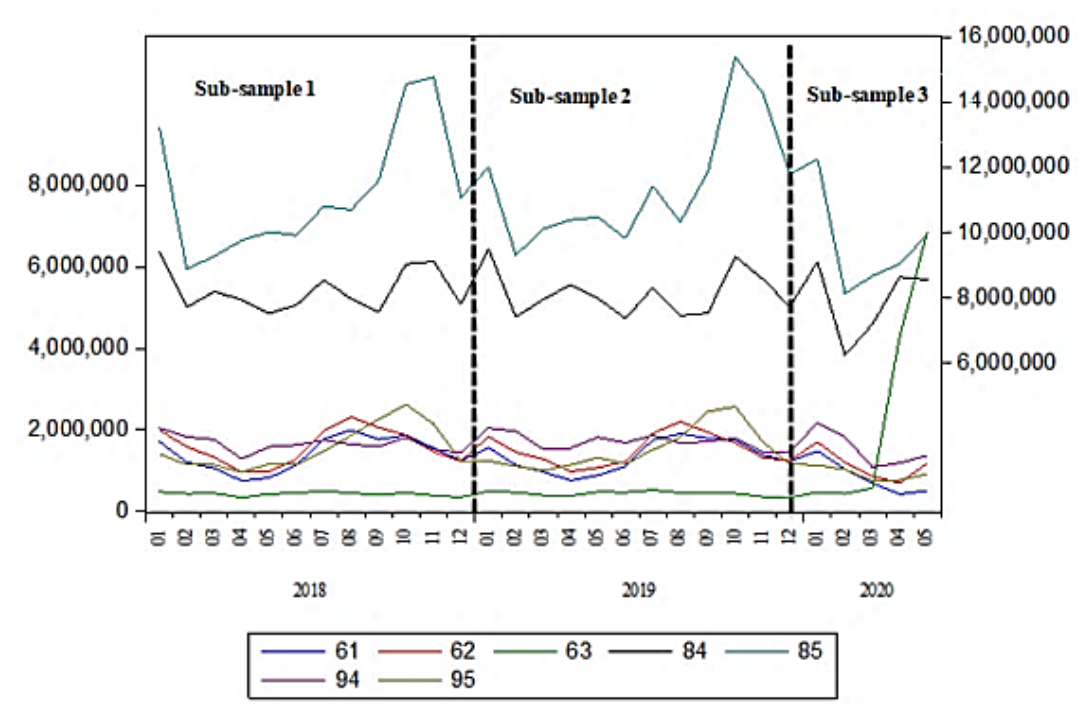

Figure 4. EU Import Values (\$) of the Selected Articles. Source: own investigation

Figure 4 presents imports from China to Europe by value and, because there are high differences among the values, we used two axes for better visibility. Machinery and electrical machinery are on the right axis, and the rest of the articles are on the left axis. The monthly values in 2018 and 2019 are similar. Thus, we cannot see any increasing or decreasing trend between these years. If we do not consider the COVID-19 outbreak, the expectation of 2020 is approximately comparable to 2019. The graph shows that there are decreases in all products except other made-up 
textiles. The product 63 (other made-up textiles) is 569,370 in February 2020, 4,280,354 in March 2020 and 6,848,965 in April 2020.

From February 2020 to March 2020, there is an approximately six times increase in the value of articles of apparel and clothing accessories, knitted, or crocheted. Table 2 shows the growth of the import values year over year for the monthly data. In the months of 2020, a generally negative trend occurred, but some positive growth values can also be seen. Except for the growth in other made-up textiles of April and June, they are under 1\%. The most important result is that other made-up textiles increase by more than $10 \%$. Although there was a decrease in all selected products except other made-up textiles in March, we can see increases in some products in April.

Table 2. Growth of Imports Year over Year by Month

\begin{tabular}{rrrrrr}
\hline Article & 2020M01 & 2020M02 & 2020M03 & 2020M04 & 2020M05 \\
\hline 61 & -0.054 & -0.090 & -0.283 & -0.440 & -0.426 \\
62 & -0.070 & -0.174 & -0.324 & -0.295 & 0.101 \\
63 & -0.036 & -0.069 & 0.453 & 10.239 & 13.260 \\
84 & -0.042 & -0.158 & -0.097 & 0.027 & 0.073 \\
85 & 0.020 & -0.126 & -0.142 & -0.130 & -0.051 \\
94 & 0.062 & -0.069 & -0.284 & -0.233 & -0.248 \\
95 & -0.081 & -0.074 & -0.254 & -0.326 & -0.301 \\
\hline
\end{tabular}

Source: own investigation

As has been pointed out, there was an excessive demand for critical medical equipment and already before 2020 "according to U.N. Comtrade (2020) statistics, $44 \%$ of the world's exports of face masks originated from China in 2018, whereas the next largest exporters, Germany $(7 \%)$ and the United States $(6 \%)$, play a comparatively minor role" (Fuchs, Kaplan, Kis-Katos, Schmidt, Turbanisch, and Wang, 2020, p. 2). In the same direction, the previous decreasing trend of the imports of these products from China changed to an increase in March and skyrocketed in April and continued in June. We have no data after June. Nonetheless, because of the scarcity, our data show us that countries had to import these products from China. Consequently, a big new market was born for China to fill the export gap.

Another comparison can be performed using the descriptive statistics of the data, year by year. Using these descriptive statistics, we can see whether a decrease started before the outbreak. This analysis shows that the outbreak is not the only reason for the decrease. As explained above, in Table 3 , we investigate the full sample and three sub-samples. The shortcoming of the sub-samples is that the last sub-sample comprises five months only. Therefore, it is hard to compare sub-samples as such, but in Appendix Table 2, we present data for five months for each year, and we can see that we have nearly similar results in the five months. In Table 2, we saw a monthly decrease. However, if the reductions are taken into consideration cumulatively, we can see that the yearly decrease is very significant, and this is shown in Table 3. However, we still must not forget that the last sub-sample consists of five months only. Therefore, we use the values in Table 1 in the Appendix to compare.

Table 3. Descriptive Statistics (\$) of Imports of EU15 for Sample and Subsamples

\begin{tabular}{cccccccc}
\hline & \multicolumn{7}{c}{ Full Sample: 2018M1-2020M5 } \\
\hline & NUM61 & NUM62 & NUM63 & NUM84 & NUM85 & NUM94 & NUM95 \\
\hline Mean & 1285428 & 1476925 & 792090.5 & 8140256 & 11036792 & 1658351 & 1425262 \\
Median & 1229408 & 1327073 & 452994 & 7975091 & 10487219 & 1677890 & 1164118 \\
Maximum & 1988541 & 2309169 & 6848965 & 9523103 & 15399976 & 2167602 & 2618489 \\
Minimum & 422081 & 691252 & 336282 & 6251098 & 8141200 & 1087124 & 746971 \\
\hline & & \multicolumn{7}{c}{ Sub-Sample 1: 2018M1-2018M12 }
\end{tabular}




\begin{tabular}{cccccccc}
\hline Mean & 1407178 & 1585570 & 426874.2 & 8221273 & 11222301 & 1656535 & 1546398 \\
Median & 1396908 & 1519353 & 437501.5 & 7964327 & 10761701 & 1636406 & 1318125 \\
Maximum & 1988541 & 2309169 & 502077 & 9396193 & 14776106 & 2042685 & 2618489 \\
Minimum & 747201 & 963059 & 336282 & 7526866 & 8887623 & 1287016 & 958312 \\
\hline & & \multicolumn{7}{c}{ Sub- Sample 2: 2019M1-2019M12 } \\
\hline Mean & 1353785 & 1512676 & 436980.2 & 8136009 & 11442748 & 1714300 & 1514464 \\
Median & 1302985 & 1386272 & 454031.5 & 7975481 & 10960053 & 1696231 & 1275664 \\
Maximum & 1903140 & 2203444 & 522960 & 9523103 & 15399976 & 2041324 & 2567207 \\
Minimum & 754189 & 980167 & 339827 & 7372026 & 9315948 & 1468159 & 1000972 \\
\hline & & & Sub- Sample 3: 2020M1-2020M5 & & 920450.6 \\
\hline Mean & 829170.4 & 1130372 & 2520875 & 7956009 & 9617274 & 1528431 & 917360 \\
Median & 697866 & 1184598 & 569370 & 8574588 & 9048216 & 1369158 & 1138412 \\
Maximum & 1480600 & 1704720 & 6848965 & 9119727 & 12261592 & 2167602 \\
Minimum & 422081 & 691252 & 433576 & 6251098 & 8141200 & 1087124 & 746971 \\
\hline
\end{tabular}

When comparing the mean of the first five months of 2019 (see Appendix Table 2) with the mean of the first five months of 2020; the mean value of apparel knitted decreases by $22 \%$, apparel not knitted by $14.7 \%$, machinery by $3.7 \%$, electrical machinery by $8 \%$, furniture by $14 \%$, and toys by $20 \%$. We also observe significant decreases in all the other products. However, the group of other made-up textiles (code 63) increases four times.

This increase in the whole group 63 is a result of the imports of COVID-19 medical supplies. To understand this in more details the product number of COVID-19 medical supplies was investigated. The World Customs Organization presents the HS/CN8 classification reference list for the dataset (WCOOMD, 2020). In the list "Facemasks (excl. paper surgical masks - under B6)" the section's H.S. code is 63079010. Also, in the TradeMap website, the COVID-19 articles are coded 630790. The definition of 630790 is made-up articles of textile materials, incl. dress patterns, n.e.s. This sub-product has a proportion of $97 \%$ of the value of article 63 in the fifth month of 2020 and its proportion was increasing during the previous months (See Appendix Table 3). This data then proves that the increase in the article 63 is a result of COVID-19 medical supplies. The increase is shown by the shift in the demand curve to up-right (an increase in the demand curve). Fuchs, Kaplan, Kis-Katos, Schmidt, Turbanisch, and Wang (2020) stated that "the demand for critical medical equipment has skyrocketed" and, based on this demand, the supply of these goods has increased. The data show that China has a great share of the international trade in protective masks.

\subsection{Import to China from Europe}

To investigate bilateral trade, we also have to discuss the imports into China from the EU15. The data was collected from the same source but, in this case, the published data has included two more months. Therefore, our data set finishes in the seventh month of 2020.

Following the COVID-19 crisis, China reported January and February 2020 in a consolidated dataset, and it is not possible to allocate trade data to January and February separately. For this reason, the two months are missing in the TradeMap website of China. Also, we checked the data from The General Administration of Customs of the People's Republic of China (GACC, 2020) in this source, there is no data for January, but we can find data for February. Unfortunately, there is no data for the EU15 country group. The data are given country by country, but some countries are

\footnotetext{
4 http://english.customs.gov.cn/Statics/c64e11ba-2208-43a1-b9b9-a618b6b419cb.html
} 
missing from the group of EU 15 countries. Based on this situation and to use data from the same source, we use TradeMap data, and there are no data for these two months.
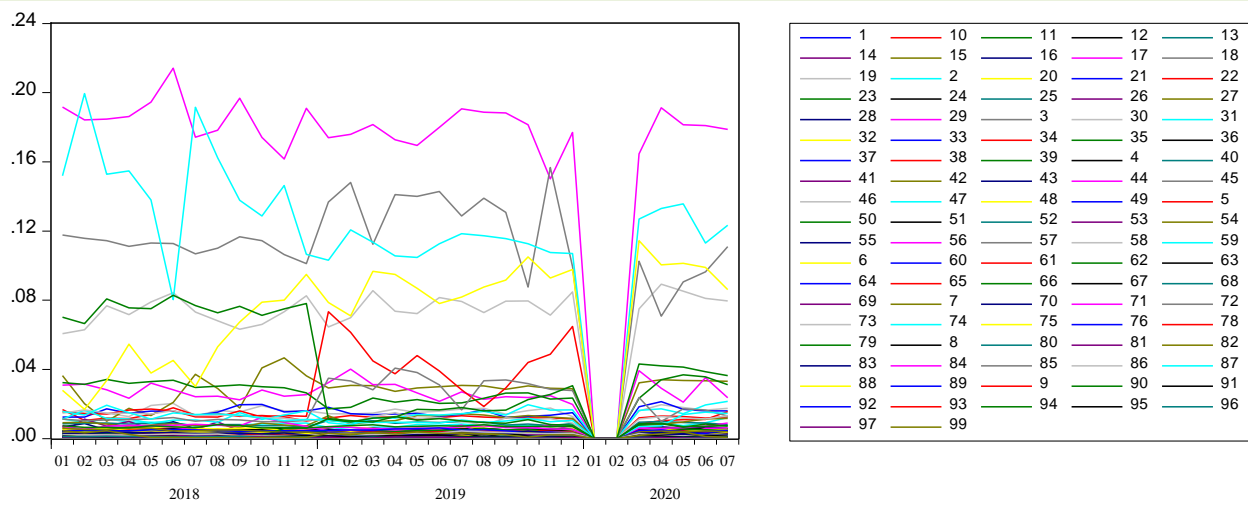

Figure 5. China Import Shares of the Articles by year. Source: own investigation

Figure 5 shows the share of the products in the total imports of China from the EU15. We chose the products with the codes $38,88,30,84,85$, and 87 because their shares are $5 \%$ or higher in at least one month. The label of the codes can be seen in the Appendix. For simplicity, we use pharmaceutical products for 30 , chemical products for 38 , machinery for 84 , electrical machinery for 85 , vehicles for 87 , and aircraft for 88 .

The first thing we need to explain is that there was an absence of any imports from the EU to China in January 2020. There was a negative balance of trade between the regions in January, according to Eurostat. This was a result of a combination of COVID-19 and the Lunar Holiday.

"China's foreign trade dropped sharply in January and February, affected by the combined effects of an extended Lunar New Year holiday and COVID-19 that disrupted the output and the supply chain." ${ }^{5}$

Figure 6 shows the monthly movement of the shares of imported products on total imports organized in product products, similarly as for exports above.

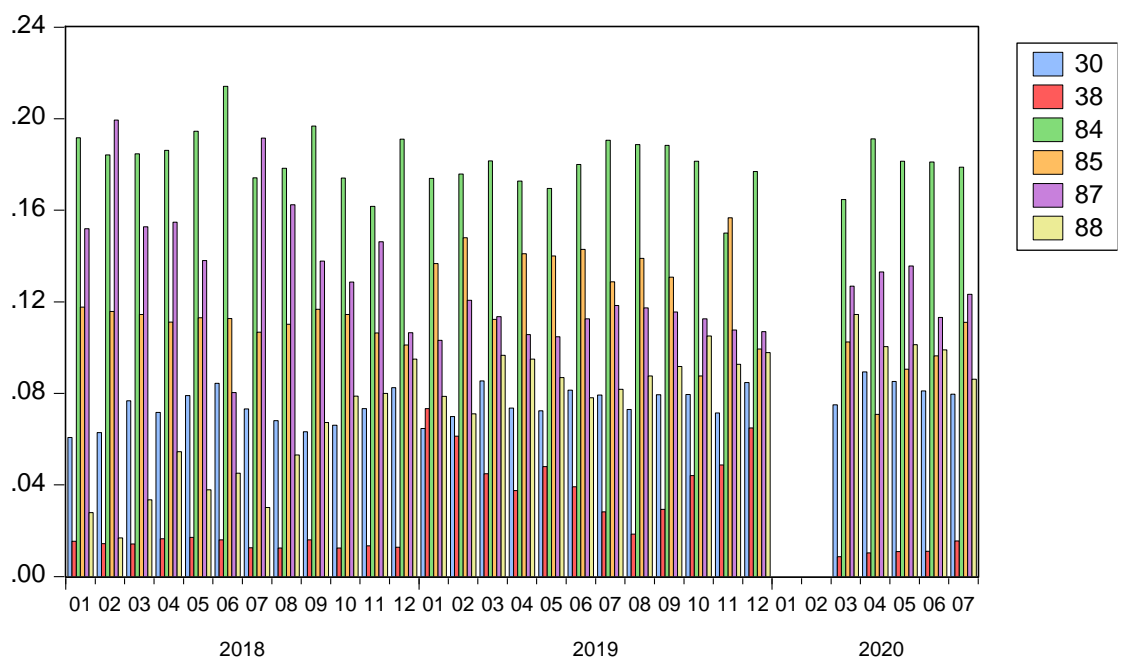

Figure 6. China Imports - Shares of the Selected Articles. Source: own investigation

5 See China Jan.-Feb. imports and exports drop dragged by coronavirus disruption CGTN 08-Mar-2020 https://news.cgtn.com/news/2020-03-07/China-Jan-Feb-imports-and-exports-drop-due-to-coronavirus-disrupti on-OEWZfoIWn6/index.html accessed on September 27, 2020. 
Figure 7 shows imports from the EU15 countries to China by value. The first difference between the import to the EU15 and the imports to China is that there was no trade shown in two months. The figure has no pattern; thus, we can say that Chinese trade preferences are not stationary. Preferences are very varying except for pharmaceutical products. The graph of the pharmaceutical products is very smooth and varies in the range from \$1 000000 to $\$ 1500000$. In such a case, it will be better to use descriptive statistics to analyze the trend of selected variables. Nevertheless, there is still the problem that we have no trade numbers for two months, and it is difficult to compare the results with the last year because of this gap.

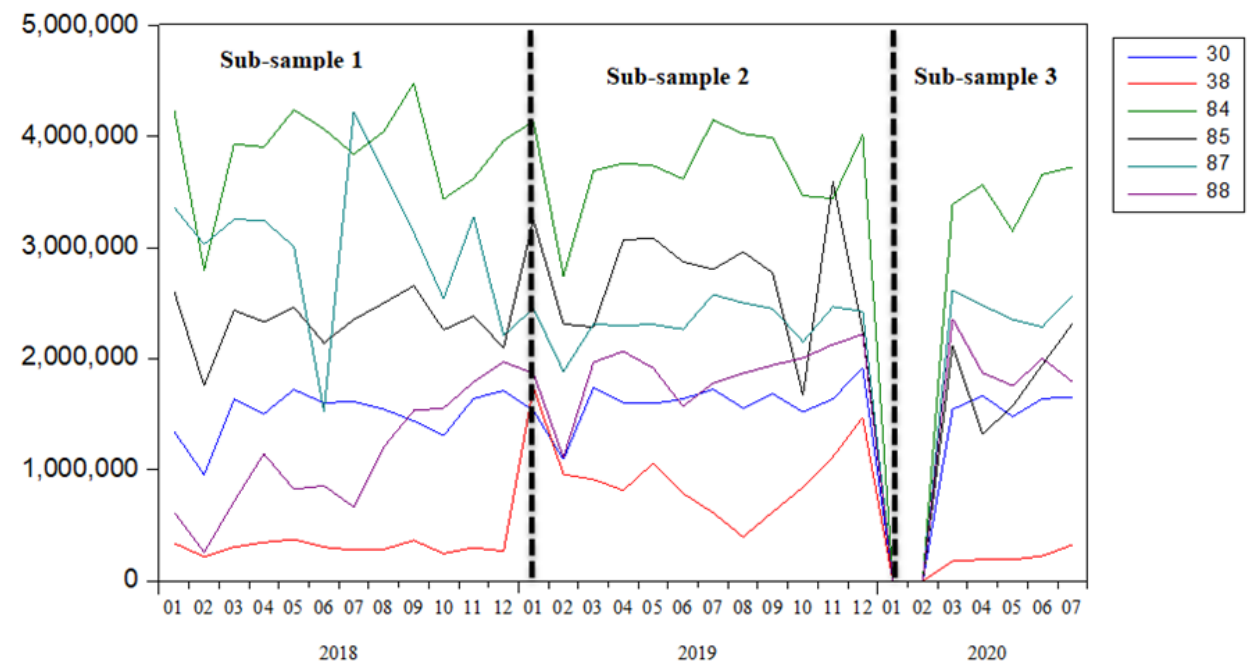

Figure 6. China Import Values (\$) of the Selected Articles. Source: own investigation

Table 4 shows the value of imports into China from the EU15 countries. When we run a comparison of 2018, 2019, and 2020 using descriptive statistics, we arrive at the same results as shown in Figure 6. While the imports of the EU15 countries from China by products have more or less stable values, the imports of China from the EU15 countries by products are very volatile. These bilateral data show that the EU has a persistent volume by products, but China changes its import volume by products.

Table 4. Descriptive Statistics (\$) of Imports of EU15 for Sample and Subsamples

\begin{tabular}{ccccccc}
\hline \multicolumn{7}{c}{ Full Sample: 2018M1-2020M5 } \\
\hline Nean & 1459678 & 518176.1 & 3510942 & 2263949 & 2480467 & 1463185 \\
Median & 1601644 & 339343 & 3737261 & 2331764 & 2468119 & 1780512 \\
Maximum & 1923510 & 1744547 & 4480002 & 3592016 & 4224355 & 2358516 \\
Minimum & 0 & 0 & 0 & 0 & 0 & 0 \\
\hline Mean & 1501560 & 301640.2 & 3880981 & 2332115 & 3041179 & 1094295 \\
Median & 1574215 & 300993.5 & 3948032 & 2368840 & 3190941 & 1000459 \\
Maximum & 1721508 & 373008 & 4480002 & 2656162 & 4224355 & 1970217 \\
Minimum & 955347 & 218077 & 2798245 & 1759266 & 1526977 & 256271 \\
\hline \multirow{7}{c}{ Sub-Sample 1: 2018M1-2018M12 } & & \\
\hline Mean & 1603821 & 944961.4 & 3731426 & 2744238 & 2341251 & 1870302 \\
Median & 1619598 & 878009 & 3748640 & 2837042 & 2368507 & 1929143 \\
Maximum & 1923510 & 1744547 & 4149695 & 3592016 & 2577854 & 2218981
\end{tabular}




\begin{tabular}{ccccccc} 
Minimum & 1091655 & 395332 & 2746431 & 1672875 & 1884365 & 1108927 \\
\hline \multicolumn{7}{c}{ Sub- Sample 3: 2020M1-2020M5 } \\
\hline Mean & 1140776 & 157748.4 & 2498614 & 1323742 & 1757901 & 1397652 \\
Median & 1543766 & 189105 & 3391672 & 1572577 & 2354924 & 1793891 \\
Maximum & 1665898 & 322685 & 3724381 & 2313849 & 2613641 & 2358516 \\
Minimum & 0 & 0 & 0 & 0 & 0 & 0 \\
\hline
\end{tabular}

Source: own investigation

The decrease in imports into China is very high in comparison with that of imports into the EU15 countries. The reason for this difference is the two months, January and February of 2020, which have no imports from the EU15 countries. In these two months, Chinese imports from the world are recorded as zero, too.

If we take into consideration bilateral data, China has not cut exporting products to the World after COVID-19, but it has cut importing products from the world, including the EU Although China's exports to the EU15 decreased, the exports of surgical masks, disposable face masks, and single-use drapes increased four times after the outbreak. We expect that the missing link explaining the decrease in imports can be found in a severe reduction in production in the first months of the year.

A further issue that is worth analyzing is the effect of the interruption of Chinese production due to COVID-19 on the environment. This issue deserves particular study for which there is no room in this paper. Looking briefly at the impact on the environment, we can see the effect of the COVID-19 outbreak on environmental issues. Authors Chen, Zhao, Lai, Wang, and Xia (2019) studied the impact of economic growth and renewable and non-renewable energy consumption on $\mathrm{CO}_{2}$ emissions at the regional level in China. The authors showed that there were bidirectional causalities between renewable energy consumption, $\mathrm{CO} 2$ emissions and economic growth in the long-term between Chinese regions. Further environmental effects were documented by Zambrano-Monserrate, Ruano and Sanchez-Alcalde (2020) and Wang and Su (2020). Further links need to be explored between the interruption of Chinese production and imports.

\section{Conclusion, Limitations and Further Research}

In this paper, we have explored the trend of trade between China and the EU Our findings show that the Chinese economy was very flexible in these challenging times, and it was able to reorient its production of export articles very quickly. We are tempted to recall the term Creative Destruction coined by J.A. Schumpeter back in 1942 in his book, "Capitalism, socialism, and democracy". Nevertheless, this particular destruction was not the same - called for by disruptive innovations like the invention of new technology. This re-orientation was simply caused by necessity - survival needs. It was caused by objective circumstances of the world pandemic.

Up to now, in the first five months of 2020, we have witnessed the re-orientation of the Chinese economy to producing new highly demanded goods, mainly to articles which are strongly linked with healthcare and related medical equipment. Chinese production and exports changed the commodity structure. The main export articles became products classified in the group H.S. 63 (Other made-up textile articles; sets; worn clothing and worn textile articles; rags) as the result of enabling the production of medical goods in high demand. Concerning Chinese imports, we have witnessed the break in January due to the combined effects of COVID-19 and the Lunar Holiday. This will surely call for further exploration when more data is available. However, the explanation may be that, since Chinese production almost stopped because of COVID-19, imports decreased sharply as well. Furthermore, judging from the stream of literature devoted to the environmental effects of the interruption of Chinese production, we can expect significant effects in the long term. The effects of Chinese flexibility can also be seen in the behavior of Chinese capital markets, which correlates with the real economy, see Chong, Wu and Su (2020).

Some reservations to our results need to be acknowledged. We confess that the results of this research are being created during the times of an on-going pandemic when source data is not yet 
fully settled and statistically verified and adjusted. However, we think that this cannot be soberly expected. Consequently, we still might expect some changes in results during the course of this year, 2020.

A topic for future research may be the further exploration of Chinese production flexibility. In this paper, we have stressed that the Chinese were very flexible in changing the structure of exports, which was triggered by this COVID-19 crisis. To verify the flexibility of the Chinese economy, we suggest looking into Chinese reactions to previous crises, e.g., the financial crisis in 2008, or the earlier Asian crisis in 1997-1998 and comparing the results.

Supplementary Materials: There were no supplementary materials employed

Author Contributions: Conceptualization, I.J. and EU; methodology, EU; validation, I.J. and EU; formal analysis, I.J. and EU; investigation, EU; resources, EU; data curation, EU; writing-original draft preparation, I.J. and EU; writing - review and editing, I.J. and EU; visualization, EU; supervision, I.J.; project administration, I.J.; funding acquisition, I.J. Both authors have read and agreed to the published version of the manuscript.,

Funding: This research was funded by a Metropolitan University Prague grant from the Institutional Fund for the Long-term Strategic Development of Research Organizations. The research did not receive any external funding.

Acknowledgments: This paper is the result of the Metropolitan University Prague research project no. 74-02 "Territorial Studies, Economics, International Relations" (2020) based on a grant from the Institutional Fund for the Long-term Strategic Development of Research Organizations. The authors also acknowledge the useful feedback given by the participants of the 8th edition of the International Scientific Conference IFRS: Global Rules \& Local Use - Beyond the Numbers organized jointly by the Anglo-American University in Prague and Metropolitan University Prague

Conflicts of Interest: The authors declare no conflicts of interest.

\section{Appendix A}

No other supplementary data was used for this article.

\section{Appendix B}

Table 1. Names of export articles

\begin{tabular}{cl}
\hline No & \\
\hline 1 & Live animals \\
2 & Meat and edible meat offal \\
3 & Fish and crustaceans, molluscs and other aquatic invertebrates \\
4 & Dairy produce; birds eggs; natural honey; edible products of animal origin, not elsewhere ... \\
5 & Products of animal origin, not elsewhere specified or included \\
6 & Live trees and other plants; bulbs, roots, and the like; cut flowers and ornamental foliage \\
7 & Edible vegetables and certain roots and tubers \\
8 & Edible fruit and nuts; peel of citrus fruit or melons \\
9 & Coffee, tea, maté and spices \\
10 & Cereals \\
11 & Products of the milling industry; malt; starches; inulin; wheat gluten \\
12 & Oil seeds and oleaginous fruits; miscellaneous grains, seeds, and fruit; industrial or medicinal ... \\
13 & Lac; gums, resins and other vegetable saps and extracts \\
14 & Vegetable plaiting materials: vegetable products not elsewhere specified or included \\
15 & Animal or vegetable fats and oils and their cleavage products; prepared edible fats; animal ... \\
\hline
\end{tabular}


Preparations of meat, of fish or of crustaceans, molluscs or other aquatic invertebrates

Sugars and sugar confectionery

Cocoa and cocoa preparations

Preparations of cereals, flour, starch, or milk; pastrycooks products

Preparations of vegetables, fruit, nuts, or other parts of plants

Miscellaneous edible preparations

Beverages, spirits, and vinegar

Residues and waste from the food industries; prepared animal fodder

Tobacco and manufactured tobacco substitutes

Salt; sulphur; earths and stone; plastering materials, lime, and cement

Ores, slag, and ash

Mineral fuels, mineral oils, and products of their distillation; bituminous substances; mineral ... Inorganic chemicals; organic or inorganic compounds of precious metals, of rare-earth metals, ...

Organic chemicals

Pharmaceutical products

Fertilizers

Tanning or dyeing extracts; tannins and their derivatives; dyes, pigments and other colouring ...

Essential oils and resinoids; perfumery, cosmetic or toilet preparations

Soap, organic surface-active agents, washing preparations, lubricating preparations, artificial ...

Albuminoidal substances; modified starches; glues; enzymes

Explosives; pyrotechnic products; matches; pyrophoric alloys; certain combustible preparations

Photographic or cinematographic goods

Miscellaneous chemical products

Plastics and articles thereof

Rubber and articles thereof

Raw hides and skins (other than furskins) and leather

Articles of leather; saddlery and harness; travel goods, handbags, and similar containers; articles ...

Furskins and artificial fur; manufactures thereof

Wood and articles of wood; wood charcoal

Cork and articles of cork

Manufactures of straw, of esparto or of other plaiting materials; basketware and wickerwork

Pulp of wood or of other fibrous cellulosic material; recovered (waste and scrap) paper or ...

Paper and paperboard; articles of paper pulp, of paper or of paperboard

Printed books, newspapers, pictures, and other products of the printing industry; manuscripts, ...

Silk

Wool, fine, or coarse animal hair; horsehair yarn and woven fabric

Cotton

Other vegetable textile fibres; paper yarn and woven fabrics of paper yarn

Man-made filaments; strip and the like of man-made textile materials

Man-made staple fibres

Wadding, felt and nonwovens; special yarns; twine, cordage, ropes and cables and articles thereof

Carpets and other textile floor coverings

Special woven fabrics; tufted textile fabrics; lace; tapestries; trimmings; embroidery 
59 Impregnated, coated, covered, or laminated textile fabrics; textile articles of a kind suitable ...

$60 \quad$ Knitted or crocheted fabrics

61 Articles of apparel and clothing accessories, knitted or crocheted

62 Articles of apparel and clothing accessories, not knitted or crocheted

63 Other made-up textile articles; sets; worn clothing and worn textile articles; rags

64 Footwear, gaiters, and the like; parts of such articles

$65 \quad$ Headgear and parts thereof

66 Umbrellas, sun umbrellas, walking sticks, seat-sticks, whips, riding-crops, and parts thereof

67 Prepared feathers and down and articles made of feathers or of down; artificial flowers; articles ...

68 Articles of stone, plaster, cement, asbestos, mica, or similar materials

69 Ceramic products

$70 \quad$ Glass and glassware

71 Natural or cultured pearls, precious or semi-precious stones, precious metals, metals clad ...

$72 \quad$ Iron and steel

$73 \quad$ Articles of iron or steel

$74 \quad$ Copper and articles thereof

$75 \quad$ Nickel and articles thereof

$76 \quad$ Aluminium and articles thereof

$78 \quad$ Lead and articles thereof

79 Zinc and articles thereof

80 Tin and articles thereof

81 Other base metals; cermets; articles thereof

82 Tools, implements, cutlery, spoons, and forks, of base metal; parts thereof of base metal

83 Miscellaneous articles of base metal

84 Machinery, mechanical appliances, nuclear reactors, boilers; parts thereof

85 Electrical machinery and equipment and parts thereof; sound recorders and reproducers, television ...

86 Railway or tramway locomotives, rolling stock and parts thereof; railway or tramway track fixtures ...

87 Vehicles other than railway or tramway rolling stock, and parts and accessories thereof

88 Aircraft, spacecraft, and parts thereof

89 Ships, boats, and floating structures

90 Optical, photographic, cinematographic, measuring, checking, precision, medical or surgical ...

$91 \quad$ Clocks and watches and parts thereof

92 Musical instruments; parts and accessories of such articles

93 Arms and ammunition; parts and accessories thereof

94 Furniture: bedding, mattresses, mattress supports, cushions and similar stuffed furnishings; ...

95 Toys, games, and sports requisites; parts and accessories thereof

96 Miscellaneous manufactured articles

97 Works of art, collectors' pieces, and antiques

99 Commodities not elsewhere specified

Table 2. Comparison of the First Five Months of exports

\begin{tabular}{lllllll}
\hline \multicolumn{8}{c}{ 2018M1-2018M5 } \\
\hline NUM61 & NUM62 & NUM63 & NUM84 & NUM85 & NUM94 & NUM95 \\
\hline
\end{tabular}




\begin{tabular}{cccccccc}
\hline Mean & 1109953 & 1370011 & 423097 & 8158951 & 10237934 & 1700424 & 1164220 \\
Median & 1063323 & 1327073 & 432193 & 7953563 & 9768318 & 1759653 & 1148836 \\
Maximum & 1717022 & 1993574 & 478563 & 9396193 & 13214381 & 2042685 & 1404459 \\
Minimum & 747201 & 963059 & 336282 & 7526866 & 8887623 & 1287016 & 958312 \\
\hline \multicolumn{7}{c}{ 2019M1-2019M5 } \\
\hline Mean & 1063365 & 1326123 & 441647.2 & 8262721 & 10467730 & 1779002 & 1161496 \\
Median & 973579 & 1288951 & 465476 & 7991856 & 10396900 & 1820083 & 1143198 \\
Maximum & 1565175 & 1833292 & 489775 & 9523103 & 12018003 & 2041324 & 1312633 \\
Minimum & 754189 & 980167 & 380832 & 7422726 & 9315948 & 1517852 & 1000972 \\
\hline
\end{tabular}

Table 3. Proportion of specification 630790 in product 63

\begin{tabular}{lrrr}
\hline & 63 & 630790 & $630790 / 63$ \\
\hline 2019M01 & 489775 & 153409 & 0.313223 \\
\hline 2019M02 & 465476 & 134854 & 0.289712 \\
\hline 2019M03 & 391869 & 115517 & 0.294785 \\
\hline 2019M04 & 380832 & 111539 & 0.292882 \\
\hline 2019M05 & 480284 & 136707 & 0.284638 \\
\hline 2019M06 & 466901 & 134050 & 0.287106 \\
\hline 2019M07 & 522960 & 163014 & 0.311714 \\
\hline 2019M08 & 455069 & 152969 & 0.336145 \\
\hline 2019M09 & 452994 & 157314 & 0.347276 \\
\hline 2019M10 & 439513 & 145793 & 0.331715 \\
\hline 2019M11 & 358262 & 120512 & 0.336380 \\
\hline 2019M12 & 339827 & 115992 & 0.341327 \\
\hline 2020M01 & 472108 & 153868 & 0.325917 \\
\hline 2020M02 & 433576 & 127763 & 0.294673 \\
\hline 2020M03 & 569370 & 396780 & 0.696875 \\
\hline 2020M04 & 4280354 & 4109009 & 0.959969 \\
\hline 2020M05 & 6848965 & 6660971 & 0.972551 \\
\hline
\end{tabular}

\section{References}

Akcigit, U., \& Ates, S. T. (2019). What Happened to U.S. Business Dynamism? (No. w25756). National Bureau of Economic Research

Balding, C. (2019). What's Causing China's Economic Slow down. Foreign Affairs.

Baldwin, R., \& di Mauro, B. (2020). Economics in the Time of COVID-19. In R. Baldwin, \& B. di Mauro, Thinking ahead about the trade impact of COVID-19 (pp. 59-71). London: CEPR Press.

Bencivelli L., Tonelli F. (2020) China in the Global Economy. In: China's International Projection in the Xi Jinping Era. Springer Briefs in Economics. Springer, Cham. https://doi.org/10.1007/978-3-030-54212-2_3

Bekkers, E., Koopman, R., \& Rego, C. L. (2020). Structural change in the Chinese economy and changing trade relations with the world. China Economic Review, 101573.

Carreño, I., Dolle, T., Medina, L., \& Brandenburger, M. (2020). The Implications of the COVID-19 Pandemic on Trade. European Journal of Risk Regulation, 11(2), 402-410. doi:10.1017/err.2020.48 
Chen, Y., Zhao, J., Lai, Z., Wang, Z., \& Xia, H. (2019). Exploring the effects of economic growth, and renewable and non-renewable energy consumption on China's CO2 emissions: Evidence from a regional panel analysis. Renewable energy, 140, 341-353.

China - Economic Forecasts - 2020-2022 Outlook https://tradingeconomics.com/china/ forecast

China Economic Outlook available at https://www.focus-economics.com/countries/china

China Jan.-Feb. imports and exports drop dragged by coronavirus disruption https://news.cgtn.com/news/2020-03-07/China-Jan-Feb-imports-and-exports-drop-due-to-coronavirus-dis ruption-OEWZfoIWn6/index.html

Chong, T. T. L., Wu, Y., \& Su, J. (2020). The Unusual Trading Volume and Earnings Surprises in China's Market. Journal of Risk and Financial Management, 13(10), 244. doi:10.3390/jrfm13100244

Civín, L., \& Smutka, L. (2020). Vulnerability of European Union Economies in Agro Trade. Sustainability, 12(12), 5210 .

Del Rio Lopez, P., \& Gordo Mora, E. (2019). World Economic Outlook for 2019. Banco de Espana Article, 5-19.

Fernandes, N. (2020). Economic effects of coronavirus outbreak (COVID-19) on the world economy. Available at SSRN 3557504.

Fuchs, A., Kaplan, L. C., Kis-Katos, K., Schmidt, S., Turbanisch, F., \& Wang, F. (2020). Mask wars: China's exports of medical goods in times of COVID-19. Available at SSRN 3661798.

GACC, (2020). Imports and Exports by H.S. Section and Division, 1-2. 2020 Retrieved December 12, 2020, from http://english.customs.gov.cn/Statics/c64e11ba-2208-43a1-b9b9-a618b6 b419cb.html

Gruszczynski, L. (2020). The COVID-19 Pandemic and International Trade: Temporary Turbulence or Paradigm Shift? European Journal of Risk Regulation, 11(Special Issuec2), 337-342.

Halicioglu, F., \& Ketenci, N. (2018). Output, renewable, and non-renewable energy production, and international trade: Evidence from EU-15 countries. Energy, 159, 995-1002. doi: 10.1016/j.energy.2018.06.197

IBIS WORLD (2020). The fastest growing industries in China: https://www.ibisworld.com/china/industry-trends/fastest-growing-industries/

Jin, X., Li, D. D., \& Wu, S. (2016). How will China shape the world economy? China Economic Review (40), 272-280.

Justin Yifu Lin (2011). China and the global economy, China Economic Journal, 4:1, 1-14, DOI: 10.1080/17538963.2011.609612

McAleer, M. (2020). Prevention Is Better Than the Cure: Risk Management of COVID-19. J. Risk Financial Manag 13,46

Oravský, R.; Tóth, P.; Bánociová, A. (2020). The Ability of Selected European Countries to Face the Impending Economic Crisis Caused by COVID-19 in the Context of the Global Economic Crisis of 2008. J. Risk Financial Manag., 13, 179.

Paital, B., Das, K., \& Parida, S. (2020). Inter nation social lockdown versus medical care against COVID-19, a mild environmental insight with special reference to India. Science of The Total Environment, (728), 1-18.

Schumpeter, J. A., 1942. Capitalism, socialism, and democracy. London: Routledge 1 online resource (xxii, 437 pages) s. Dostupné online. ISBN 0-585-46039-6, ISBN 978-0-585-46039-0. OCLC 52758517

The Economic Times News (2018) Trump threatens to impose tariffs on countries Retrieved December 12, 2020 from https://economictimes.indiatimes.com/news/international/world-news/trump-threatens-to-impose -tariffs- on-countries/articleshow/66338047.cms

Thorbecke, W. (2020) The Impact of the COVID-19 Pandemic on the U.S. Economy: Evidence from the Stock Market. J. Risk Financial Manag, 13, 233.

TradeMap (2020). Trade Map User Guide Trade statistics for international business. Retrieved 9 10, 2020, from TradeMap.org: https://www.TradeMap.org/Docs/TradeMap-Userguide-EN.pdf

UNIDO, (2020). Coronavirus: the economic impact - July 10, 2020 | Retrieved September 12, 2020, from https://www.unido.org/stories/coronavirus-economic-impact-10-july-2020

Wang, C.; Cheng, Z.; Yue, X.-G.; McAleer, M. (2020). Risk Management of COVID-19 by Universities in China. J. Risk Financial Manag, 13, 36.

Wang, Q., \& Su, M. (2020). A preliminary assessment of the impact of COVID-19 on environment-A case study of China. Science of the Total Environment, 138915. 
Wen, X., Ma, H., Choi, T., \& Sheu, J. (2019). Impacts of the Belt and Road Initiative on the China-Europe trading route selections. Transportation Research Part E: Logistics And Transportation Review, 122, 581-604. doi: 10.1016/j.tre.2019.01.006

WTO, (2019). Retrieved September 12, 2020, from https://www.wto.org/english/res e/statis e/wts2019 e/wts19 toc e.htm

WCOOMD (2020). H.S. classification reference for Covid-19 medical supplies 2.1 Edition, Retrieved December 12 2020, from http://www.wcoomd.org/-/media/wco/public/global/pdf/topics/nomenclature/covid 19/hsclassification-reference 2 1-24 4 20 en.pdf?la=en

Wu, Y.-C., Chen, C.-S. and Chan, Y.-J. (2020). The outbreak of COVID-19: An overview, Journal of the Chinese Medical Association: 83(3): 217-220

Xu, X. (2019). The Slowdown of China's Economic Growth in Terms of Statistics. Frontiers of Economics in China, 14(1), 72-79.

Yüksel, S., Dinçer, H., \& Meral, Y. (2019). Financial Analysis of International Energy Trade: A Strategic Outlook for EU-15. Energies, 12(3), 431. doi: 10.3390/en1203043

Zambrano-Monserrate, M. A., Ruano, M. A., \& Sanchez-Alcalde, L. (2020). Indirect effects of COVID-19 on the environment. Science of the Total Environment, 138813.

Zhang, W.; Wang, Y.; Yang, L.; Wang, C. (2020). Suspending Classes Without Stopping Learning: China's Education Emergency Management Policy in the COVID-19 Outbreak. J. Risk Financial Manag. 13, 55. 